\title{
The Utilization of Fixed Bed Coal Gasification By-Products to Produce Combustible Gas by Auto-thermal Process
}

\author{
N. Nurhadi \#, M. Ade Andriansyah Efendi ${ }^{\#}$, and Sapta Rianda ${ }^{\#}$ \\ ${ }^{\#}$ R\&D Center for Mineral and Coal Technology (tekMIRA), Ministry of Energy and Mineral Resources, Bandung, 40211, Indonesia \\ E-mail: ade.andriansyah@esdm.go.id
}

\begin{abstract}
Fixed bed gasification of coal generate some by-products, such as tar and coal powder. Coal powder obtained because the coal feed for fixed bed gasification reactor must have a size above $20 \mathrm{~mm}$. Meanwhile, tar is a high molecular weight hydrocarbon compounds that will condense at low temperatures, which cause clogging and blocking of pipes. In this study, experiment on combustible gas generation from co-gasification of tar and coal powder was conducted in an auto-thermal reactor to determine the temperature of the process, combustible gas composition, and efficiency of the process. From calculation and experiments about oxidizing reactor operation, $20 \mathrm{~kg} / \mathrm{hr}$ of tar was more promising to operate and can reach the optimal temperature which was $1900^{\circ} \mathrm{C}$. The energy from oxidizing reactor used for the reduction reaction of tar and pyrolysis of coal powder and produce combustible yield gas. The coal powder that can be conversion was about $14.4 \mathrm{~kg} / \mathrm{hr}$ and produce approximately $84.52 \mathrm{~kg} / \mathrm{hr}$ combustible gas. The calorific value of combustible yield gas amounted to $783.62 \mathrm{Cal} / \mathrm{g}$. Combustible yield gas has advantages levels of hydrogen gas $\left(\mathrm{H}_{2}\right)$ as high as $19.2 \%$, which is already exceeding the levels of hydrogen gas from coal gasification is only <10\%. Cold gas efficiency (CGE) has a value which was still low at $26.31 \%$. It is caused by two factors, namely the calorific value fuel gas produced was still low and the remainder of the conversion of coal powder were still mostly in the form of charcoal.
\end{abstract}

Keywords - tar reforming; combustible gas; carbon conversion; cold gas efficiency.

\section{INTRODUCTION}

Coal is an alternative energy source than petroleum, coal consumption in the country is the biggest to the needs of power plants, while for other industries such as cement, steel, and small industry is still relatively small. Indonesian coal production and consumption will continue to increase in line with economic growth and energy needs [1]. Coal can be converted into combustible gas through gasification process. Besides generate combustible gas, fixed bed coal gasification can also produce some by-products, such as ash, tar, and coal powder. Coal powder obtained because the coal feed for fixed bed gasification reactor must have a size above $20 \mathrm{~mm}$. Meanwhile, tar is a high molecular weight hydrocarbon compounds [2],[3],[4]. Tar will condense at low temperatures, which cause clogging and blocking of pipes, valves, filters, engine and fuel cell stack. Tar can be removed by physical processes that use scrubbers, carbon adsorption and electrostatic precipitator [5]. Increased temperature gasification is a promising approach to reduce the formation of tar [2]. Houben et al. [3] carried out tar reduction through partial combustion burner of a combustible gas experiment. In his study, naphthalene is added as a model tar component. For higher air/fuel ratio values, the total tar content slightly decreases. At lower air fuel ratio and higher hydrogen concentrations, the tar content strongly decreases. It is found that the partial combustion burner reduces the tar content of the gas with over $90 \%$ by cracking with an air/fuel ratio of 0.2 .

Many studies show that partial oxidation temperature of tar range from 600 to $1300^{\circ} \mathrm{C}$. Stravinkas et al. [6] reported that tar destruction was performed in a fixed bed reactor at temperatures from $700{ }^{\circ} \mathrm{C}$ to $900{ }^{\circ} \mathrm{C}$, with the steam-tocarbon ratio $\left(\mathrm{H}_{2} \mathrm{O} / \mathrm{C}\right)$ from 0 to 1 , air equivalence ratio (ER) from 0 to 0.5 at a constant space velocity and the initial concentration of $\operatorname{tar} 21.1 \pm 1.89 \mathrm{~g} / \mathrm{m} 3$. The thermal destruction of tar was found to be most intensive in terms of both tar destruction and hydrogen gas production when using steam reforming at $900^{\circ} \mathrm{C}$ and $\mathrm{H}_{2} \mathrm{O} / \mathrm{C}=1$. Under these conditions, an almost complete conversion of tar was achieved, with benzene as the only remainder at a concentration of $0.019 \mathrm{~g} / \mathrm{m}^{3}$. In the experiment of Ma et al. [7], a combined system of an oxygen carrier material (OCM) and a catalyst for the partial oxidation of naphthalene (as a model component for tar) will be introduced. OCMs are 
able to incorporate oxygen ions into the crystal lattice. The oxygen stoichiometry of the ceramic material depends significantly on oxygen partial pressure and temperature. The properties of the OCMs were examined in a long-term four-cycle experiment. In the first cycle, the pre-oxidation phase occurs. In this phase, the OCM was fully oxidized during heating up to $900^{\circ} \mathrm{C}$ with $25 \mathrm{~cm}^{3} \mathrm{~min}^{-1}$ air flow. The OCM was then heated up to $800^{\circ} \mathrm{C}$ in this reducing atmosphere. Because of the low $\mathrm{O}_{2}$ partial pressure, the oxygen stored in the OCM would then be released in this reduction phase. In combination with the combined catalyst and oxygen carrier system, the use of $\mathrm{H}_{2} \mathrm{~S}$ sorbent further enhanced the performance of the catalyst. In conclusion, the suitable oxygen carrier materials, catalyst and sour gas sorbent could be identified, which in combination enable the proposed tar removal process.

Ahrenfeldt et al. [8] found that practically all phenol is converted at temperatures above $950^{\circ} \mathrm{C}$. The resulting polycyclic aromatic hydrocarbons (PAH) tar compounds are readily converted in the subsequent char-bed of the Two Stage gasification process and the partial oxidation process thus contributes directly as well as indirectly to the overall tar destruction. A high temperature and excess air ratios contribute positively to the direct tar destruction and a high moisture content of the biomass enhances the decomposition of phenol and inhibits the formation of naphthalene. Ma and Muller [9] reported that four perovskite-type oxide materials and $\mathrm{NiO}$ were tested regarding their catalytic activity for partial oxidation of naphthalene as model tar from biomass gasification. Using these catalysts, at least $60 \%$ of naphthalene was converted above $600^{\circ} \mathrm{C}$. $\mathrm{NiO}$, which is reduced to $\mathrm{Ni}$ under gasification conditions, showed the highest catalytic activity of all tested materials with about $95 \%$ conversion at $600^{\circ} \mathrm{C}$.

Partial oxidation over a wide temperature range from 1100 to $1400^{\circ} \mathrm{C}$ was studied by Tsuboi et al. [10]. They were investigated regenerative reforming of light and heavy tars contained in syngas by steam gasification. In a first step, basic design parameters of the reformer such as an appropriate size of the reactor and amount of oxidant were determined by using numerical predictions. The results showed that the appropriate average temperature in the reactor, necessary minimal residence time and oxygen flow rate are $1300^{\circ} \mathrm{C}, 4 \mathrm{~s}$ and $12 \%$ of the syngas volume, respectively. Experiments with the new regenerative tar reformer proved stable operation and reforming efficiency exceeding $99 \%$ at an oxygen flow-rate of $11.3 \%$. This result also proved that the concept of regenerative reformer yields higher system efficiency because the same high reforming efficiency as obtained with a conventional reformer could be achieved with $30 \%$ less oxygen consumption. In the comparison of two oxygen nozzle designs, four holes yield higher efficiencies $\left(\eta_{\operatorname{tar}}\right)$ than a one-hole nozzle due to better mixing of syngas and oxygen. It was found that the formation of a high-temperature zone has a strong effect on high reforming efficiency. Zhao et al. [11] also investigated the tar components, tar conversion rates, a physical and chemical structure of biochar after reaction at the second stage were sampled and analyzed. Results showed that at $700^{\circ} \mathrm{C}$, the coupling of char and oxygen could result in the significant improvement of tar conversion rate $(89.32 \%)$ than both two separated method $(85.1 \%$ and $86.14 \%)$. At $900^{\circ} \mathrm{C}$, the synergy effect could reach the highest conversion rate of $95.84 \%$.

Van der Hoeven et al. [12] also investigated partial producer gas combustion for tar reduction. The study showed that the influence of ambient gas such as hydrogen on thermal tar conversion can probably be derived from the chemical balance of the reactions taking place. The addition of a certain ambient gas can generate driving forces which can direct or redirect species balance of reactions. The results showed that a rising hydrogen content is always beneficial for increased tar cracking, by increased reaction rates, increased free radical production, and increased radical residence times. Therefore, to obtain best tar cracking by partial product gas combustion, the product gas should have a high hydrogen content.

Based on the few studies that have been conducted, tar was converted using a reagent mixture of oxygen-steam or air-steam causing partial combustion of the chemical reaction as follows:

$$
\begin{aligned}
& \mathrm{C}_{\mathrm{x}} \mathrm{H}_{\mathrm{y}} \mathrm{O}_{\mathrm{z}}+\mathrm{O}_{2} \leftrightarrow \mathrm{CO}+\mathrm{H}_{2} \\
& \mathrm{C}_{\mathrm{x}} \mathrm{H}_{\mathrm{y}} \mathrm{O}_{\mathrm{z}}+\mathrm{H}_{2} \mathrm{O} \leftrightarrow \mathrm{CO}+\mathrm{H}_{2}
\end{aligned}
$$

The reaction is exothermic and endothermal, so overall not require additional heat from outside the system. Autothermal conversion technology is known as partial oxidation (partial oxidation, POX). Comparison of different pitch conversion technology can be seen in Fig.1.

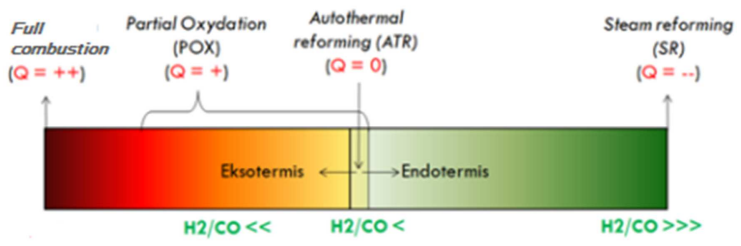

Fig 1. Conversion technology into a combustible gas [13]

However, the existing processes have not resolved the problem of another by-product which is coal powder. To overcome these problems, an innovative gasification process that considers the tar oxidation and coal powder gasification stages in the reactor is proposed. The tar oxidation stage is designed for tar combustion fed with air. As the temperature rises to the desired temperature, tar added to the partial oxidation reactor and the coal powder was added to the reforming reactor to serve as gasification raw materials during the process. The gasification-required heat was provided by the oxidation/combustion reactor. This gasification technology operates in the different reactor; thus, all the heat of coal combustion can supply the reforming/gasification stage, which is better for tar cracking and can effectively prevent the sintering of raw materials in the gasification process. Based on this technology, on combustible gas generation from co-gasification of tar and coal powder was conducted in an auto-thermal reactor to determine the temperature of the process, combustible gas composition, and efficiency of the process. 


\section{MATERIAL AND METHOD}

Experiments were performed at atmospheric pressure, auto-thermal, and gasification system. Fig. 1 presents the schematic of the gasification system, which mainly includes an auto-thermal gasifier, two separated feeders (tar and coal), a high-temperature cyclone separator, a temperature controller, a tube type heat exchanger, and a chimney. Process flow diagram of research equipment shown in Fig.2.

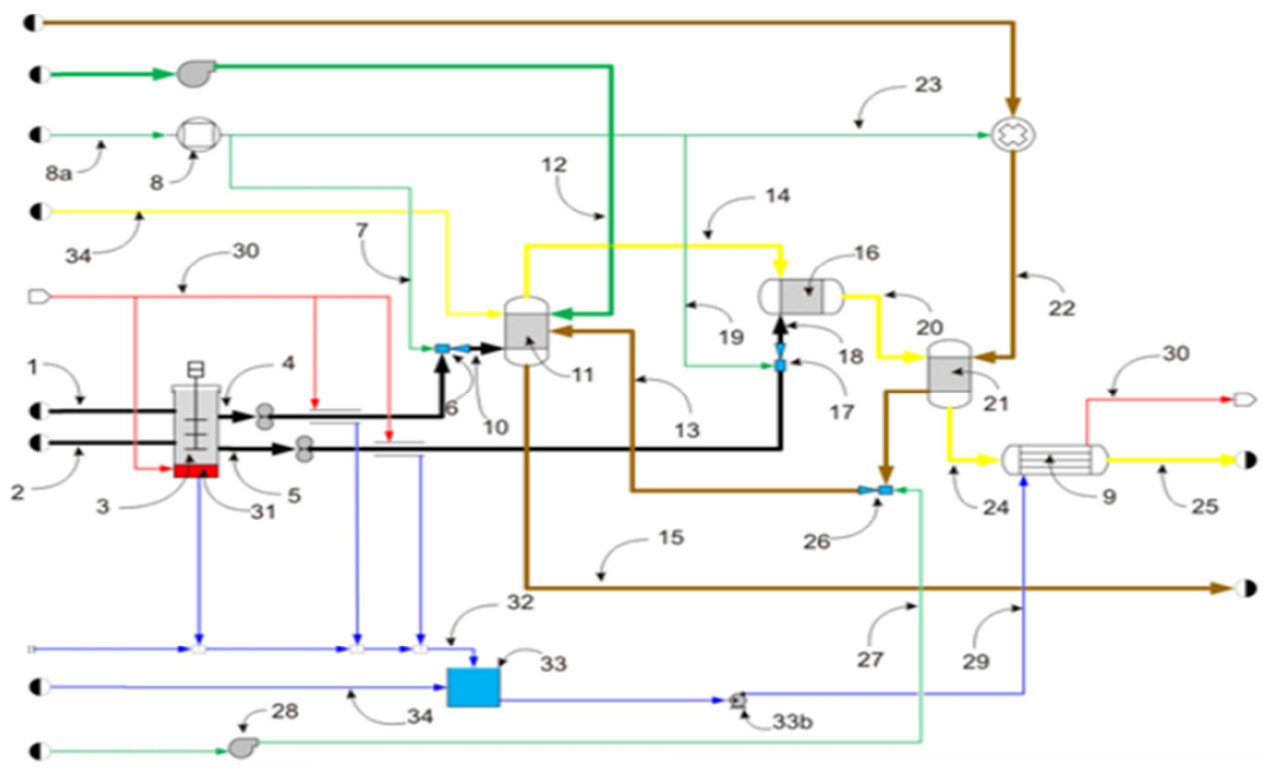

Fig 2. Process flow diagram of research equipment.

The flow rate of tar to the oxidation chamber set at $15 \mathrm{~L} /$ $\mathrm{hr}$. The furnace process consists of seven stages: the heating tar as fuel combustion (1) and (2) in the tank (3) to decrease the viscosity of tar so it is easy to flow into research equipment; tar combustion reaction (4) and coal powder charcoal recycle (13) with air in an oxidizing reactor (11) generates an oxidizing gas (14) and liquid ash or slag (15); reduction reaction between the oxidizing gas (14) with tar feed (5) in the reductant reactor (16) gas into a reductant gas (20); catalytic reactions reforms between reductant gas (20) with the coal powder (22), which consists of the reaction of pyrolysis of coal powder, catalytic reactions charcoal for cracking long chain hydrocarbon and the catalytic reaction of alkalis for the reduction reaction of coal powder into producer gas (24) and coal powder (13); coal powder charcoal-recycle to the oxidant (11) and as fuel for the combustion reaction; gas producer (24) is cooled by water cooling medium (29) in the waste heat boiler (9), in order to obtain steam (30); steam (30) used for the heating medium. In the gasification stage, the sample of the product gas is collected from the bell-type gas holder with a gas bag and analyzed for major components $\left(\mathrm{H}_{2}, \mathrm{CO}, \mathrm{CO}_{2}\right.$, and $\mathrm{CH}_{4}$ ).

Data processing experiments were conducted to determine the performance of the tar conversion process into combustible yield gas. Processing data includes into combustible gas composition analysis, calculation of mass balance, energy balance, carbon conversion and cold gas efficiency (CGE). The composition of fuel gas conducted to determine the composition of impervious gas fuels (combustible gasses) is $\mathrm{H}_{2}, \mathrm{CO}, \mathrm{CH}_{4}$ and $\mathrm{C}_{2}+$ and unreceptive fuel gas composition (noncombustible gasses), such as $\mathrm{CO}_{2}$ and $\mathrm{N}_{2}$. Analysis of fuel gas using gas chromatography. Mass balance calculation was conducted by calculating the flow rate of feed (tar, air and coal powder) and the calculation of the flow rate of the product (fuel gas and charcoal). Energy balance calculation was done to determine the chemical energy content in the fuel gas product. Carbon conversion was used to determine the amount of carbon from the feed (tar and coal) which converted into a fuel gas. While the cold gas efficiency (CGE) was used to determine the chemical energy in the fuel gas produced in the process of the chemical energy contained in the feed (tar and coal).

\section{RESULTS AND DISCUSSION}

\section{A. Tar Characteristics}

In this research, tar samples used were obtained from a ceramic factory PT. SANGO in Semarang, Indonesia. Laboratory analysis of the tar can be seen in Table I. The results of the laboratory analysis showed that the water content of tar was very small, which was $2 \%$, eliminating the need for separated water content.

Although tar has a low pour point, but still contains a high carbon residue, which was $10 \%$ weight, and high levels of sedimentation which was $0.36 \%$. This causes tar susceptible for coagulation when it flowed in the pipeline. One way to overcome it was by warming the tar up to 60$65^{\circ} \mathrm{C}$, then filtered using a filter with a size of 100 mesh.

After tar fed into the tank, then tar was heated using steam heated by setting the temperature $88-90^{\circ} \mathrm{C}$. This setup is done automatically using the electronic control valve regulated by a micro-controller on the control panel. Along the heating process in the tank, conducted warm up pipe flow towards the nozzle. Steam was used from the 
start-up boiler which uses LPG fuel. Start up the boiler will be shut down operations if the steam generated by Gas Cooler has been fulfilled. Gas Cooler products utilizing sensible heat gas to generate steam.

TABLE I

PROXIMATE AND ULTIMATE ANALYSIS OF TAR

\begin{tabular}{|l|c|c|l|}
\hline Parameter & Unit & Value & \multicolumn{1}{|c|}{ Method } \\
\hline Calorific value & $\mathrm{Cal} / \mathrm{g}$ & $8,650.72$ & ASTM D.4809 \\
\hline $\begin{array}{l}\text { Kinetic viscosity } \\
100^{\circ} \mathrm{C}\end{array}$ & $\mathrm{cSt}$ & 12.25 & ASTM D.445 \\
\hline Ash content & $\begin{array}{c}\% \mathrm{w} \\
\text { (weight) }\end{array}$ & 0.069 & ASTM D. 482 \\
\hline Pour point & ${ }^{\circ} \mathrm{C}$ & 30 & ASTM D.97 \\
\hline Flash point & ${ }^{\circ} \mathrm{C}$ & 136.5 & ASTM D.93 \\
\hline $\mathrm{C}$ content & $\% \mathrm{w}$ & 79.34 & ASTM D.5291 \\
\hline $\mathrm{H}$ content & $\% \mathrm{w}$ & 7.87 & ASTM D.5291 \\
\hline $\mathrm{N}$ content & $\% \mathrm{w}$ & 1.47 & ASTM D.5291 \\
\hline O content & $\% \mathrm{w}$ & 10.36 & ASTM D.5291 \\
\hline S content & $\% \mathrm{w}$ & 0.34 & ASTM D.4294 \\
\hline Water content & $\% \mathrm{w}$ & 2.0 & ASTM D.95 \\
\hline Carbon residue & $\% \mathrm{w}$ & 10.44 & ASTM D.4530 \\
\hline
\end{tabular}

\section{B. Coal Powder Characteristics}

Coal powder that used in this research was from finely unused coal in a fixed bed gasifier in Palimanan, Indonesia. Characteristics of coal can be seen in Table II. The coal powder was categorized in sub-bituminous coal. In the fixed bed gasifier, this coal powder was a byproduct because of the coal used was nut size which is over $2 \mathrm{~cm}$.

TABLE II

PROXIMATE AND ULTIMATE ANALYSIS OF COAL POWDER

\begin{tabular}{|c|c|c|c|}
\hline Parameter & Unit & Value & Method \\
\hline \multicolumn{4}{|l|}{ Proximate } \\
\hline Moisture & $\%$, adb & 14.81 & ASTM D. 3173 \\
\hline Ash & $\%, \mathrm{adb}$ & 2.32 & ASTM D. 3174 \\
\hline Volatile matter & $\%, \mathrm{adb}$ & 41.99 & ASTM D. 3175 \\
\hline Fixed Carbon & $\%, \mathrm{adb}$ & 40.88 & ASTM D.3172 \\
\hline $\begin{array}{l}\text { Gross calorific } \\
\text { value }\end{array}$ & $\begin{array}{l}\mathrm{Cal} / \mathrm{g}, \\
\mathrm{adb}\end{array}$ & 5,293 & ASTM D.5865 \\
\hline Total sulfur & $\%, \mathrm{adb}$ & 0.25 & ASTM D.4239 \\
\hline \multicolumn{4}{|l|}{ Ultimate } \\
\hline Carbon & $\%, a d b$ & 57.1 & ASTM D.5373 \\
\hline Hydrogen & $\%, \mathrm{adb}$ & 5.51 & ASTM D.5373 \\
\hline Nitrogen & $\%, \mathrm{adb}$ & 0.91 & ASTM D.5373 \\
\hline Oxygen & $\%, a d b$ & 3.31 & ASTM D.3176 \\
\hline $\begin{array}{l}\text { Hardgrove } \\
\text { Grindability Index }\end{array}$ & & 33 & ASTM D.409 \\
\hline \multicolumn{4}{|c|}{ Ash fusion temperature (reducing atmosphere) } \\
\hline $\begin{array}{l}\text { Deformation } \\
\text { temperature }\end{array}$ & ${ }^{\circ} \mathrm{C}$ & 1,212 & ASTM D.1857 \\
\hline $\begin{array}{l}\text { Spherical } \\
\text { temperature }\end{array}$ & ${ }^{\circ} \mathrm{C}$ & 1,221 & ASTM D.1857 \\
\hline $\begin{array}{l}\text { Hemisphere } \\
\text { temperature }\end{array}$ & ${ }^{\circ} \mathrm{C}$ & 1,224 & ASTM D.1857 \\
\hline Flow temperature & ${ }^{\circ} \mathrm{C}$ & 1,230 & ASTM D.1857 \\
\hline \multicolumn{4}{|c|}{ Ash fusion temperature (oxidizing atmosphere) } \\
\hline $\begin{array}{l}\text { Deformation } \\
\text { temperature }\end{array}$ & ${ }^{\circ} \mathrm{C}$ & 1,223 & ASTM D.1857 \\
\hline $\begin{array}{l}\text { Spherical } \\
\text { temperature }\end{array}$ & ${ }^{\circ} \mathrm{C}$ & 1,235 & ASTM D.1857 \\
\hline $\begin{array}{l}\text { Hemisphere } \\
\text { temperature }\end{array}$ & ${ }^{\circ} \mathrm{C}$ & 1,239 & ASTM D.1857 \\
\hline Flow temperature & ${ }^{\circ} \mathrm{C}$ & 1,283 & ASTM D.1857 \\
\hline
\end{tabular}

\section{Oxidizing Reactor Operation}

Oxidation of tar in the oxidizing reactor was conditioned to obtain optimal conditions of heat that can be supplied for tar conversion into fuel gas in reductant reactor. Fig 3. shows the correlations between the flow rate of air used to burn the tar of temperatures in the oxidizing agents with different tar feed, which were 5, 10, 15, and $20 \mathrm{~kg} / \mathrm{hr}$. Air flow rate varied according to the needs of stoichiometric combustion of tar (70-150\% stoichiometric). As reference was the stoichiometric air requirement burning $100 \%$ of each feed tar, which was $47 \mathrm{~m}^{3} / \mathrm{hr}$ of air for $5 \mathrm{~kg} / \mathrm{hr}$ of tar, $94 \mathrm{~m}^{3} / \mathrm{hr}$ of air for $10 \mathrm{~kg} / \mathrm{hr}$ of tar, $141 \mathrm{~m}^{3} / \mathrm{hr}$ of air for 15 $\mathrm{kg} / \mathrm{hr}$ of tar, and $188 \mathrm{~m}^{3} / \mathrm{hr}$ of air for $20 \mathrm{~kg} / \mathrm{hr}$ of tar.

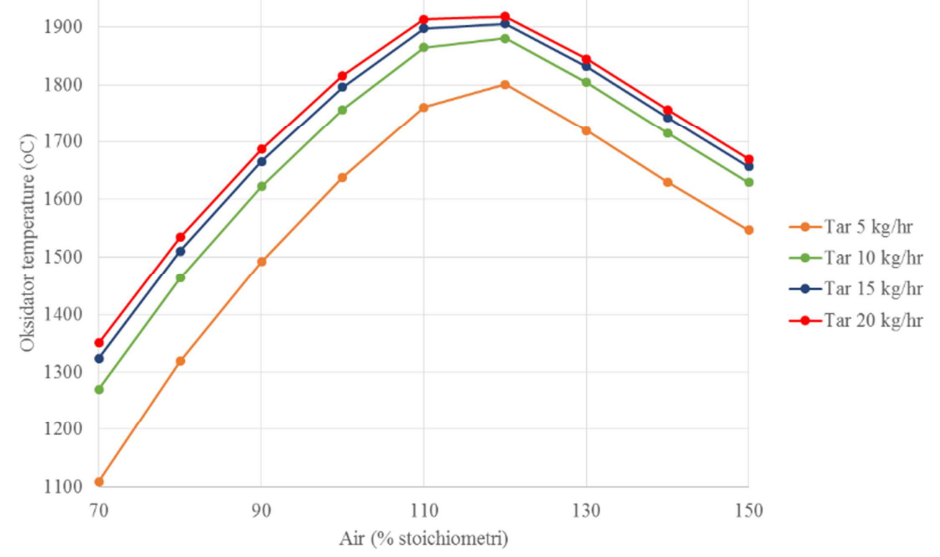

Fig 3. Correlations of the flow rate of air and temperature in the oxidizing reactor.

In Fig 3., it can be seen that the combustion in the oxidizing reactor reached $1,900^{\circ} \mathrm{C}$. This condition was obtained when the tar feed at $20 \mathrm{~kg} / \mathrm{hr}$ with $110-120 \%$ stoichiometric air. But after passing $120 \%$ stoichiometric air, the heat was generated slowly began to decline. At the time of the burning, tar was able to be burned until $120 \%$ stoichiometric air. When air was supplied above $120 \%$ stoichiometry, tar that be burned is not available anymore and the heat generated is absorbed by the excess air. The air is represented by the amount of unburned oxygen in the flue gas in which can be seen in Fig 4.

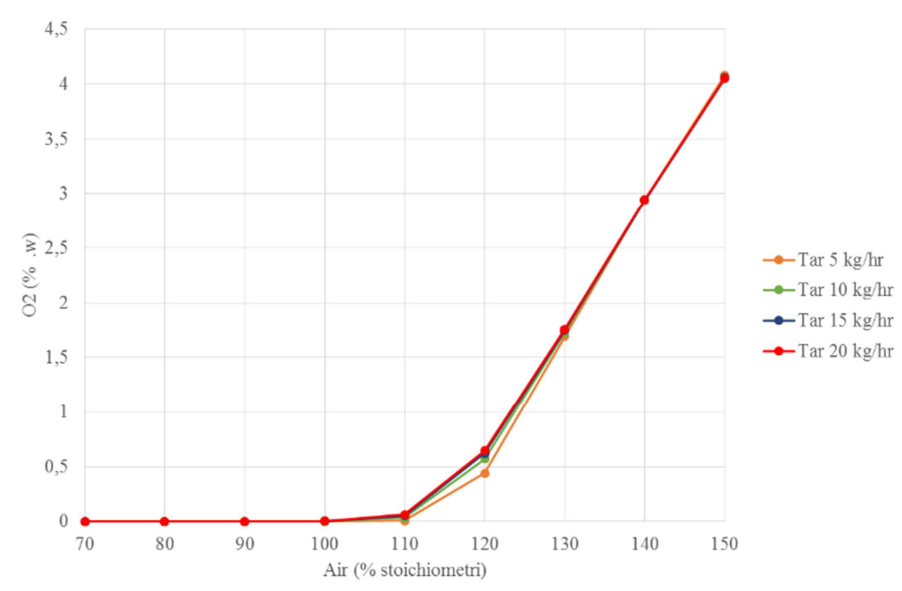

Fig 4. Correlations of the air flow rate and the oxygen content in the flue gas.

The amount of oxygen began to rise drastically after the stoichiometric air passing through $120 \%$. Furthermore, the indicator of the temperature drop in oxidizing reactor was the presence of carbon dioxide $\left(\mathrm{CO}_{2}\right)$ as shown in Fig 5 . 
Complete combustion reaction produces $\mathrm{CO}_{2}$ and $\mathrm{H}_{2} \mathrm{O}$ [14]. The amount of $\mathrm{CO}_{2}$ reached record levels at $120 \%$ stoichiometric air. After passing these conditions, the amount of $\mathrm{CO}_{2}$ begins to decline.

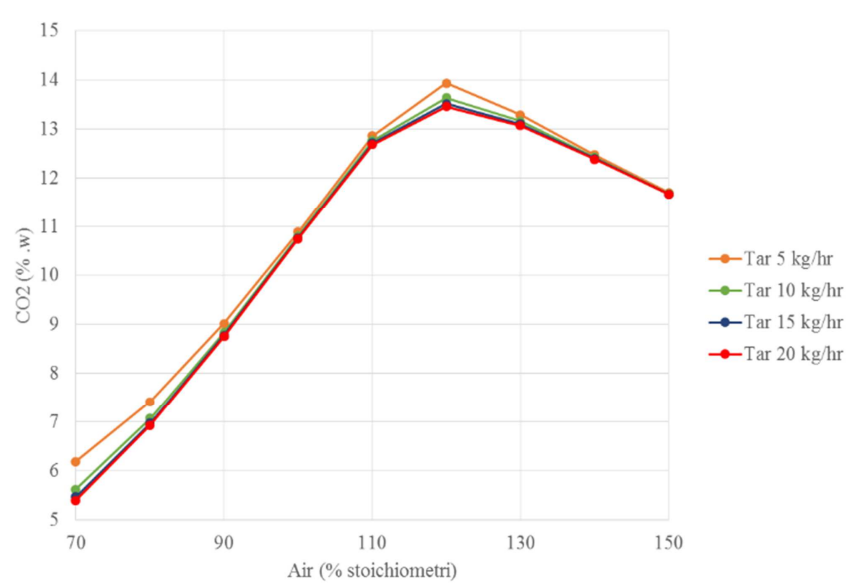

Fig 5. Correlations of the air flow rate and the carbon dioxide content in the flue gas.

The amount of nitrogen dioxide $\left(\mathrm{NO}_{2}\right)$, which is the emission on combustion, is also influenced by the presence of $\mathrm{O}_{2}$ [15]. $\mathrm{NO}_{2}$ has increased more than $120 \%$ when the air stoichiometry, as shown in Fig 6.

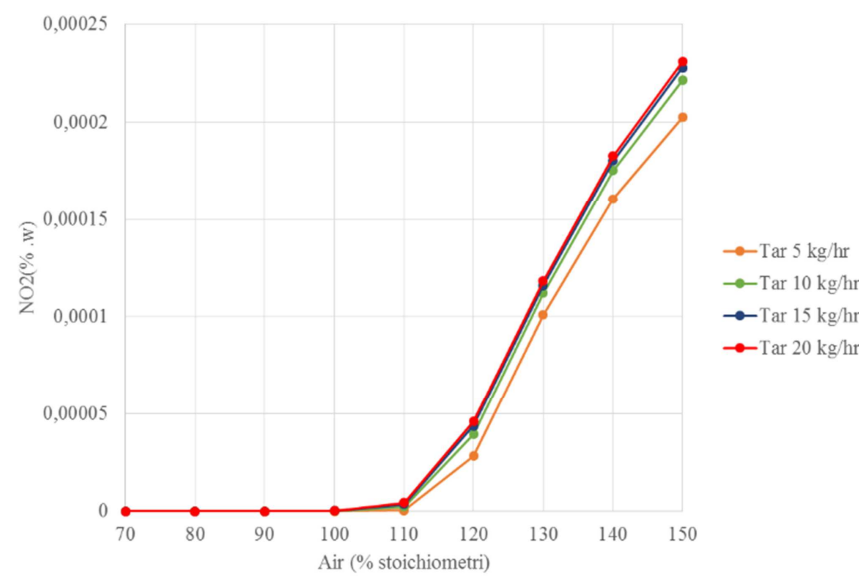

Fig 6. Correlations of the air flow rate and the nitrogen dioxide content in the flue gas.

Nitrogen contained in the fuel can be bound with oxygen to form oxides with varying degrees of oxidation [16]. Inversely with $\mathrm{NO}_{2}$, sulfur dioxide $\left(\mathrm{SO}_{2}\right)$ in the oxidizing reactor has decreased, it is caused by a drop in temperature in the reactor. When the temperature increases, the formation reaction of $\mathrm{SO}_{2}$ will be more slowly that decrease the amount of $\mathrm{SO}_{2}$, as shown in Fig 7.

On the number of different tar feed, oxidizing reactor temperature and gas content will be almost equal. However, the air flow rate varied according to stoichiometry, so that in the larger tar feed, the reactor conditions become more stable. In Fig 3. and Fig 5., for $5 \mathrm{~kg} / \mathrm{hr}$ of tar, the process looks more volatile than $20 \mathrm{~kg} / \mathrm{hr}$ of tar. Therefore the feed of $20 \mathrm{~kg} / \mathrm{hr}$ of tar was easier to operate and more promising than with smaller amount, in addition to consideration of the optimal temperature that can be reached was $1,900^{\circ} \mathrm{C}$.

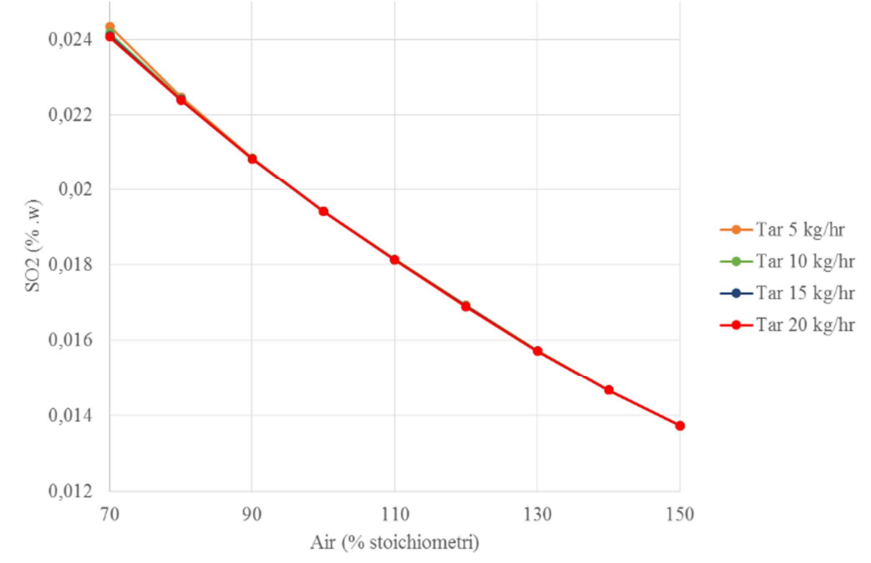

Fig 7. Correlations of the air flow rate and the sulfur dioxide content in the flue gas.

\section{Combustible Yield Gas}

The calorific value of combustible yield gas amounted to $783.62 \mathrm{Cal} / \mathrm{g}$ as shown in Table III. It still can be improved by increasing the gas content of carbon monoxide $(\mathrm{CO})$ and reduce carbon dioxide $\left(\mathrm{CO}_{2}\right)$ through the reduction reaction of $\mathrm{CO}_{2}$ to $\mathrm{CO}$ in the reactor reductants. Combustible yield gas has advantages levels of hydrogen gas $\left(\mathrm{H}_{2}\right)$ as high as $19.2 \%$, which is already exceeding the levels of hydrogen gas from coal gasification is only $<10 \%$. Hydrogen gas is the fuel that is environmentally friendly because it does not produce the greenhouse effect [17]. This is due to feed tar has a chemical composition ratio $\mathrm{H} / \mathrm{C}$ which is higher than coal.

TABLE III

RESULTS ANALYSIS OF COMBUSTIBLE YIELD GAS

\begin{tabular}{|l|c|c|}
\hline Parameter & Unit & Value \\
\hline $\mathrm{H}_{2}$ & \% vol. & 19.2 \\
\hline $\mathrm{O}_{2}$ & \% vol. & 0 \\
\hline $\mathrm{N}_{2}$ & \% vol. & 50.80 \\
\hline $\mathrm{CH}_{4}$ & \% vol. & 0.5 \\
\hline $\mathrm{CO}$ & \% vol. & 8 \\
\hline $\mathrm{CO}_{2}$ & \% vol. & 19.3 \\
\hline $\mathrm{C}_{2}+$ & \% vol. & 2.2 \\
\hline Total & \% vol. & 100 \\
\hline \multicolumn{2}{|l|}{} & \\
\hline Calorific value & $\mathrm{Cal} / \mathrm{g}$ & 783.62 \\
\hline
\end{tabular}

\section{E. Efficiency}

Calculation of efficiency conversion process tar and coal powder into gas fuel can be seen in Table IV. Coal powder was fed into the reformer reactor and will be pyrolyzed into fuel gas and charcoal. The gas flow rate in the reformer reactor occur more quickly, so coal powder will be carried in the gas stream and leave the reformer reactor in a shorter time.

Cold gas efficiency (CGE) has a value which was still low at $26.31 \%$ compared to gasification which have efficiency $50-70 \%$ [18]. It is caused by two factors, namely the calorific value fuel gas produced was still low and the remainder of the conversion of coal powder were still mostly in the form of charcoal. Table IV showed the coal 
powder that was converted into gas, which amounted 14.4 $\mathrm{kg} / \mathrm{hr}$.

TABLE IV

COLD GAS EFFICIENCY ANALYSIS OF AUTO-THERMAL CONVERSION PROCESS

\begin{tabular}{|l|c|c|c|}
\hline \multirow{2}{*}{ Parameter } & \multicolumn{2}{|c|}{ Inlet } & Outlet \\
\cline { 2 - 4 } & Tar & Coal powder & $\begin{array}{c}\text { Combustible } \\
\text { gas }\end{array}$ \\
\hline Flow (kg/hr) & 20 & 14.4 & 84.52 \\
\hline $\begin{array}{l}\text { Calorific Value } \\
(\mathrm{Cal} / \mathrm{g})\end{array}$ & $8,560.72$ & 5,293 & 783.62 \\
\hline Energy (kCal/hr) & $175,545.45$ & $76,219.25$ & $66,228.21$ \\
\cline { 2 - 3 } & \multicolumn{3}{|c|}{$251,764.75$} \\
\hline $\begin{array}{l}\text { Cold Gas } \\
\text { Efficiency (\%) }\end{array}$
\end{tabular}

\section{IV.CONCLUSION}

An experiment on combustible gas generation from cogasification of tar and coal powder was conducted in an auto-thermal reactor to determine the temperature of the process, combustible gas composition, and efficiency of the process. From calculation and experiments about oxidizing reactor operation, $20 \mathrm{~kg} / \mathrm{hr}$ tar was more promising to operate and can reach the optimal temperature which was $1,900^{\circ} \mathrm{C}$. The energy from oxidizing reactor used for the reduction reaction of tar and pyrolysis of coal powder and produce combustible yield gas. Coal powder was fed into the reformer reactor and will be pyrolyzed into fuel gas and charcoal. The coal powder that can be conversion was about $14.4 \mathrm{~kg} / \mathrm{hr}$ and produce approximately $84.52 \mathrm{~kg} / \mathrm{hr}$ combustible gas. The calorific value of combustible yield gas amounted to $783.62 \mathrm{Cal} / \mathrm{g}$. It still can be improved by increasing the gas content of carbon monoxide $(\mathrm{CO})$ and reduce carbon dioxide $\left(\mathrm{CO}_{2}\right)$ through the reduction reaction of $\mathrm{CO}_{2}$ to $\mathrm{CO}$ in the reactor reductants. Combustible yield gas has advantages levels of hydrogen gas $\left(\mathrm{H}_{2}\right)$ as high as $19.2 \%$, which is already exceeding the levels of hydrogen gas from coal gasification is only $<10 \%$. Hydrogen gas is the fuel that is environmentally friendly because it does not produce the greenhouse effect. This is due to feed tar has a chemical composition ratio $\mathrm{H} / \mathrm{C}$ which is higher than coal. Cold gas efficiency (CGE) has a value which was still low at $26.31 \%$ compared to gasification which have efficiency 50-70. It is caused by two factors, namely the calorific value fuel gas produced was still low and the remainder of the conversion of coal powder were still mostly in the form of charcoal.

\section{ACKNOWLEDGMENT}

The authors would like to thank the R\&D Center for Mineral and Coal Technology (tekMIRA), Ministry of Energy and Mineral Resources, who has funded this research.

\section{REFERENCES}

[1] M. Faizal, "Utilization Biomass and Coal Mixture to Produce Alternative Solid Fuel for Reducing Emission of Green House Gas," International Journal on Advanced Science, Engineering and Information Technology, vol. 7, no. 3, pp. 950-956, 2017.

[2] P. Gilbert, C. Ryu, V. Sharifi, and J. Swithenbank, "Tar reduction in pyrolysis vapors from biomass over a hot char bed," Bioresour. Technol., vol. 100, no. 23, pp. 6045-6051, 2009.

[3] M. P. Houben, H. C. De Lange, and a. a. Van Steenhoven, "Tar reduction through partial combustion of fuel gas," Fuel, vol. 84, no. 7-8, pp. 817-824, 2005.

[4] D. Singh, E. Hernández-Pacheco, P. N. Hutton, N. Patel, and M. D. Mann, "Carbon deposition in an SOFC fueled by tar-laden biomass gas: A thermodynamic analysis," J. Power Sources, vol. 142, no. 12, pp. 194-199, 2005.

[5] J. Han and H. Kim, "The reduction and control technology of tar during biomass gasification/pyrolysis: An overview," Renew. Sustain. Energy Rev., vol. 12, no. 2, pp. 397-416, 2008.

[6] G. Stravinskas and V. Grigaitien, "Comparison of steam reforming and partial oxidation of biomass pyrolysis tars over activated carbon derived from the waste tire," vol. 196, pp. 67-74, 2012.

[7] M. Ma, M. Mu, J. Richter, R. Kriegel, D. Bo, and N. Ruhe, "Investigation of combined catalyst and oxygen carrier systems for the partial oxidation of naphthalene as model tar from biomass gasification," vol. 3, pp. 1-7, 2012.

[8] J. Ahrenfeldt, H. Egsgaard, W. Stelte, T. Thomsen, and U. B. Henriksen, "The influence of partial oxidation mechanisms on tar destruction in TwoStage biomass gasification," Fuel, vol. 112, pp. 662-680, 2013.

[9] M. Ma and M. Müller, "Applied Catalysis A : General Investigation of various catalysts for partial oxidation of tar from biomass gasification," "Applied Catal. A, Gen., vol. 493, pp. 121-128, 2015.

[10] Y. Tsuboi, S. Ito, M. Takafuji, H. Ohara, and T. Fujimori, "Development of a regenerative reformer for tar-free syngas production in a steam gasification process," Appl. Energy, no. x, 2016.

[11] S. Zhao, Y. Luo, Y. Zhang, and Y. Long, "Journal of Analytical and Applied Pyrolysis Experimental investigation of the synergy effect of partial oxidation and bio-char on biomass tar reduction," J. Anal. Appl. Pyrolysis, vol. 112, pp. 262-269, 2015.

[12] T. A. Van Der Hoeven, H. C. De Lange, and A. A. Van Steenhoven, "Analysis of hydrogen-influence on tar removal by partial oxidation," vol. 85, pp. 1101-1110, 2006.

[13] M. Higman, C. and van der Burgt, "Gasification: The Thermodynamics of Gasification," 2nd ed., Elsevier, 2008.

[14] L. Cundari, L. Nurul Komariah, N. Novia, I. Maretha, and L. Septiana, "Temperature Distribution of Biodiesel Blends Combustion in Boiler using CFD-Fluent," International Journal on Advanced Science, Engineering and Information Technology, vol. 6, no. 1, pp. 120-123, 2016.

[15] L. F. De Diego, M. De Obras-loscertales, A. Rufas, P. Gayán, A. Abad, and J. Adánez, "Pollutant emissions in a bubbling fluidized bed combustor working in oxy-fuel operating conditions : Effect of flue gas recirculation," Appl. Energy, vol. 102, no. x, pp. 860-867, 2013.

[16] M. De Obras-loscertales, T. Mendiara, A. Rufas, L. F. De Diego, P. Gayán, A. Abad, and J. Adánez, "NO and N2O emissions in oxyfuel combustion of coal in a bubbling fluidized bed combustor," Fuel, vol. 150, pp. 146-153, 2015.

[17] C. M. Kalamaras and A. M. Efstathiou, "Hydrogen Production Technologies : Current State and Future Developments," vol. 2013, 2013.

[18] M. A. Andriansyah Efendi, and N. Nurhadi, "Comparison of an Internal Combustion Engine Derating Operated on Producer Gas from Coal and Biomass Gasification," International Journal on Advanced Science, Engineering and Information Technology, vol. 6, no. 3, pp. 385-389, 2016. 